\title{
Orchid bee baits attracting bees of the genus Megalopta (Hymenoptera, Halictidae) in Bauru region, São Paulo, Brazil: abundance, seasonality, and the importance of odors for dim-light bees
}

\author{
Fátima R. N. Knoll ${ }^{1} \&$ Leandro M. Santos ${ }^{2,3}$
}

'Laboratório de Abelhas, Departamento de Ciências Biológicas, Faculdade de Ciências, UNESP, Campus de Bauru, Caixa Postal 473,
17033-360 Bauru-SP, Brasil. knoll@fc.unesp.br
2Laboratório de Biologia Comparada de Hymenoptera, Departamento de Zoologia, Universidade Federal do Paraná, Caixa Postal 19020,
81531-980 Curitiba-PR, Brasil. megalopta@gmail.com
${ }^{3}$ Programa de Pós-Graduação em Entomologia, Bolsista CNPq.

\begin{abstract}
Orchid bee baits attracting bees of the genus Megalopta (Hymenoptera, Halictidae) in Bauru region, São Paulo, Brazil: abundance, seasonality, and the importance of odors for dim-light bees. Nocturnal bees in the genus Megalopta Smith, 1853 are generally collected using artificial light sources. However, between 1993 and 2000, a total of 946 females (no males were captured) were captured using aromatic baits commonly used for orchid bees (Euglossini) in five localities in Bauru region, São Paulo, Brazil. Aromatic compounds used in bait traps were: benzyl acetate, eucalyptol, eugenol, skatole, methyl salicylate, and vanillin. The Megalopta species collected were: M. guimaraesi ( $71.2 \%$ of total number of specimens), M. amoena (28.1\%), and M. aegis $(0.6 \%)$. Using the data from these traps, we showed that there was a positive and significant correlation between the abundance of individuals and meteorological factors, rainfall and temperature. Bees were more commonly collected in the spring (September to December) and summer (December to March) than in the autumn and winter, the latter characterized for being a drier and colder period. Variations in the abundance were also detected among localities and years. The most attractive compounds were eugenol (54\%), methyl salicylate (22\%), and eucalyptol (16\%). The ability to detect smells may have an important role in searching for flowers during dim-light conditions. We suggest the use of aromatic compounds in future studies on the biology of Megalopta in the Neotropical region.
\end{abstract}

KEYWORDS. Abundance; chemical baits; scent; seasonality.

RESUMO. Abelhas do gênero Megalopta (Hymenoptera, Halictidae) atraídas por iscas químicas usadas para euglossíneos na região de Bauru, SP: abundância, sazonalidade e importância de odores para abelhas crepusculares. Abelhas noturnas do gênero Megalopta (Smith, 1853) são geralmente coletadas usando fontes artificiais de luz. Porém entre os anos de 1993 e 2000, um total de 946 fêmeas de Megalopta foram capturadas (machos não foram capturados) usando iscas aromáticas frequentemente usadas para atração de machos de Euglossini, em cinco localidades na região de Bauru, São Paulo, Brasil. Os compostos aromáticos utilizados foram: acetato de benzila, eucaliptol, eugenol, escatol, salicilato de metila e vanilina. As espécies encontradas foram M. guimaraesi (71.2\% do total de indivíduos), M. amoena (28.1\%) and M. aegis (0.6\%). De modo geral, os resultados mostraram correlação positiva e significativa entre a abundância de indivíduos e os fatores meteorológicos considerados — precipitação pluviométrica e temperatura. As abelhas foram geralmente capturadas em maior número na primavera e verão e raramente no outono e inverno, período mais seco e frio. Variações na abundância também foram detectadas entre as localidades e entre os anos estudados. As substâncias mais atrativas foram: eugenol (54\%), salicilato de metila (22\%) e eucaliptol (16\%). A capacidade de detectar cheiros pode ter um importante papel na busca por flores em condições crepusculares. Sugerimos o uso destes compostos aromáticos em pesquisas futuras sobre a biologia de Megalopta na região Neotropical.

PALAVRAS-CHAVE: Abundância; iscas químicas; olfato; sazonalidade.

Individuals of the nocturnal bee genus Megalopta Smith, 1853, forage in dim-light conditions when most other bees do not forage (Wcislo et al. 2004; Wcislo \& Tierney 2009). Females are either solitary or facultatively social (Arneson \& Wcislo 2003; Wcislo \& Gonzalez 2006) and construct nests in dead wood (Janzen 1968; Wcislo et al. 2004; Santos et al. 2010). Megalopta occurs from tropical parts of Mexico to the state of Santa Catarina, Brazil, and contains 30 described species (Michener 2007; Engel 2011). Despite this diversity, the number of undescribed species is presumably high, and still today little is known about their natural history in South
America (Santos et al. 2010). Most of what is known about their biology comes from studies on two species (M. genalis Meado-Waldo, 1916 and M. centralis Friese, 1926) from a single locality in Central America, Barro Colorado Island, Panama (Arneson \& Wcislo 2003; Wcislo et al. 2004; Wcislo \& Gonzalez 2006).

Since most species are believed to be nocturnal or crepuscular because of their anatomical features shared with other dim-light foraging aculeate Hymenoptera (e.g., enlarged ocelli and compound eyes, pale body color, etc.), they are normally captured using artificial light sources (Wcislo \& 
Tierney 2009). However, in the region of Bauru, São Paulo state (SP), Brazil, a large number of Megalopta specimens have been collected using chemical baits that are commonly used to attract male orchid bees (Apidae, Euglossini). Such a technique has been used since the identification of various pure forms of orchid odor components (Dodson et al. 1969), and it is widely used in the Neotropical region (Nemésio 2007). The main goal of the application of these chemical baits is to collect euglossine bees, but other bees are also rarely attracted: Megalopta and Megaloptilla Moure \& Hurd, 1987 (Halictidae, Augochlorini), Ptiloglossa Smith, 1853 (Colletidae, Caupolicanini), Lestrimellita Friese, 1903 (Apidae, Apini), and Acanthopus Klug, 1807 (Apidae, Ericrocidini) (Campos et al. 1989; Melo 1995; Engel \& Brooks 1999; Gonzalez et al. 2010b; Nemésio \& Siqueira 2011); however, the significance of these unintentionally collected bees is often neglected by melittologists.

Herein we report the use of chemical baits to collect Megalopta bees. We also provide information on the meteorological (rainfall and temperature) influence on the abundance and seasonality of Megalopta based on samplings conducted between 1993 and 2000 with orchid bee baits, in five localities in Bauru region, São Paulo, Brazil. We also discuss the importance of the olfactory system in Megalopta in foraging flowers with odors in dim-light conditions.

\section{MATERIAL AND METHODS}

The study was conducted in five localities of west central São Paulo state (Bauru region). The dominant vegetation in all localities is semidecidual forest (Veloso et al. 1991), and the climate is humid subtropical (Cwa) following the classification of Köppen-Geiger, which is defined by hot summers and dry winters (Peel et al. 2007). In general, the dry season covers the period from April to August, while the wet season is from September to March.

The bees were captured in the following four fragmented areas and in the university campus in the municipalities of Bauru, Agudos, Gália, and Alvinlândia in São Paulo, Brazil.

1. Permanent Preservation Area Vargem Limpa-Campo Novo (PPAVL) in Bauru, SP. It has a total preservation area of about 1274 ha [ $22^{\circ} 21^{\prime} \mathrm{S} ; 4^{\circ} 01^{\prime} \mathrm{W} ; 580 \mathrm{~m}$ ]. The native vegetation is a forested savanna (cerradão) with a very dense tree stratum, usually with Copaifera langsdorfii, Coussarea hydrangeafolia, Siparuna guianensis, Xylopia aromatica, Vochysia tucanorum, and Myrcia guianensis (Cavassan et al. 2006). The landscape is composed of farms, pastures, and urban area.

2. Permanent Preservation Area of Duratex (PPAD). This is situated in Agudos [22 $29^{\prime}-22^{\circ} 47^{\prime} \mathrm{S}$; 48 $4^{\circ} 51^{\prime}-48^{\circ} 99^{\prime} \mathrm{W}$ ] and has an altitude of $580 \mathrm{~m}$. The fragment studied covers 94.22 ha, and it is located inside an area of 920 ha of native vegetation and introduced Pinus and Eucalyptus. It is a fragment of seasonal semideciduous forest, with the most important botanical families being Leguminosae, Rubiaceae, and Myrtaceae (Cavassan et al. 1984).
3. The Ecological Station of Bauru (ESB) is located in Bauru [22 $07^{\circ}-22^{\circ} 15^{\prime} \mathrm{S}$; $\left.49^{\circ} 04^{\prime}-49^{\circ} 05^{\prime} \mathrm{W}\right]$ and has a mean altitude of $530 \mathrm{~m}$. It is a remnant of a seasonal semideciduous forest with an area of 287 ha. The most important botanical families are Leguminosae, Rutaceae, Myrtaceae, Boraginaceae, Meliceae, and Lauraceae. It is surrounded by pastures.

4. The Ecological Station of Caetetus (ESC) is located between the municipalities of Galia and Alvinlândia [22 $22^{\prime}-$ $\left.22^{\circ} 27^{\prime} \mathrm{S}, 49^{\circ} 40^{\prime}-49^{\circ} 43^{\prime} \mathrm{W}\right]$ and has a mean altitude of 690 $\mathrm{m}$. It has an area of $2308 \mathrm{ha}$. It can be described as a seasonal semideciduous forest because it has high trees with complex stratification and high floristic diversity. The most important tree species of the upper stratum are Metrodorea nigra, Savia dictyocarpa, Ocotea indecora, Aspidosperma polyneuron, and Trichilia catigua (Durigan et al. 2000). It is surrounded by agricultural areas, mostly growing coffee.

5. Paulista State University (UNESP) Campus in Bauru (UCB) $\left[22^{\circ} 21^{\prime} \mathrm{S} ; 4^{\circ} 01^{\prime} \mathrm{W}\right]$ has an altitude of $580 \mathrm{~m}$. Its vegetation is originally forested savanna with forest representatives, but it also has ornamental and fruit-bearing plants. The size of the area is 52.47 ha and is separated from the preceding (PPAVL) by a highway (width of 50 to $60 \mathrm{~m}$ ) and surrounded by an urban area.

The bees were collected in bait traps, similar as those proposed by Campos et al. (1989). The chemical baits used were eucalyptol (cineol), eugenol, methyl salicylate, and vanillin (four different chemical compounds per station). Skatole was also used in ESB and UCB and benzyl acetate in UCB.

Traps were run from 1993 and 2000 and were located about $1.70 \mathrm{~m}$ above the ground, remaining in the field during the entire sampling period. In all areas the bait traps were separated from each other by a distance of 50 to $100 \mathrm{~m}$. In the preserved areas the sampling stations were established along a trail, as close to the center of the reserve as possible. A total of six stations were located in PPAVL (four in the interior of the bushes and two on the edge), four in both ESB and PPAD, eight in ESC, and three in UCB.

The traps were always placed on days without rainfall, approximately at 08:00 am, remaining at the site for a period from three to five days. After this period, during the daytime, the bait traps were checked and the bees collected. This procedure was repeated monthly, always at the same stations previously chosen. The monthly sample was a total number of bees collected in all stations and traps.

Monthly values of accumulated rainfall $(\mathrm{mm})$ and the average of minimum and maximum temperature $\left({ }^{\circ} \mathrm{C}\right)$ were correlated with monthly samples of abundance for M. amoena and M. guimaraesi. We used a nonparametric Spearman's rank correlation coefficient for localities studies and for cluster of data for all areas studied. Meteorological data were obtained from the Instituto de Pesquisas Meteorológicas da UNESP (IPEMET), except for ESC which was obtained from the Instituto Agronômico de Campinas (IAC).

The collected bees are deposited in Coleção Entomológica Padre Jesus Santiago Moure, Departamento de Zoologia da Universidade Federal do Paraná (DZUP), Brazil. 


\section{RESULTS}

Bee Activity. A total of 946 individuals, all females (12\% of all collected bees), of the following three Megalopta species were collected: M. aegis (Vachal, 1904), M. amoena (Spinola, 1853), and M. guimaraesi Santos \& Silveira, 2009. Most specimens belonged to M. guimaraesi $(\mathrm{n}=674)$ and the majority were captured in PPAD (Table I). Megalopta guimaraesi was the most abundant species in all four localities while $M$. amoena was more abundant only in PPAD; $M$. aegis was rarely collected and was only present in PPAVL and ESB (Table I).

Table I. Number of Megalopta bees collected in five localities in Bauru region (SP) Brazil. Permanent Preservation Area of Vargem Limpa Campo Novo (PPAVL); Permanent Preservation Area of Duratex (PPAD); Ecological Station of Bauru (ESB); Ecological Station of Caetetus (ESC) and University Campus of UNESP in Bauru, SP (UCB).

\begin{tabular}{lcccc}
\hline & M. guimaraesi & M. amoena & M. aegis & Total \\
\hline PPAVL & 248 & 45 & 5 & 298 \\
PPAD & 161 & 199 & 0 & 360 \\
ESB & 192 & 9 & 1 & 202 \\
ESC & 19 & 7 & 0 & 26 \\
UCB & 54 & 6 & 0 & 60 \\
\hline Total & 674 & 266 & 6 & 946 \\
\hline
\end{tabular}

M. guimaraesi was captured between 32 and $503 \mathrm{~mm}$ of rainfall and in temperatures between $13.6^{\circ} \mathrm{C}$ and $31.9^{\circ} \mathrm{C}$, the average monthly minimum and maximum temperature, respectively. The abundance of $M$. guimaraesi was correlated with rainfall in all areas of study. The correlation was higher and meaningful for the minimum average temperature in PPAVL, ESB, and UCB (Table II).

M. amoena was captured between 22 and $475 \mathrm{~mm}$ of rainfall and in temperatures between $12.0^{\circ} \mathrm{C}$ and $31.1^{\circ} \mathrm{C}$. The correlation of abundance and rainfall was positive and meaningful only in PPAD. The correlation of abundance and temperature was higher and meaningful in PPAVL for the average temperature minimum and maximum (Table III).

Megalopta bees were more commonly captured in the wet months of spring (September to November) and summer (December to February) than in autumn (March to May) and winter (June to August) (Figs. 1-5). The correlation between monthly abundance of $M$. guimaraesi and $M$. amoena $\left(\mathrm{r}_{\mathrm{s}}=\right.$ $0.718, \mathrm{P}=0.001$ ) sustains the similar seasonality standard between these two species. However, data show differences in the abundance among years, as observed in the springsummer of 1998/99, which was especially favorable for both species in the forest areas (PPAD, ESB and ESC), while in the cerrado of PPAVL, the highest abundance peak occurred in 1997/98 spring-summer. It also calls our attention the long periods of little abundance, or even the complete absence of

Table II. Meteorological data (rainfall and temperatures) observed in monthly samples, abundance of individuals (number and mean \pm SD) and values of Spearman's rank correlation coefficient (rs) of M. guimaraesi for all localities in Bauru region (SP), Brazil (legends are the same of Table I).

\begin{tabular}{|c|c|c|c|c|c|}
\hline & PPAVL & PPAD & ESB & ESC & $\mathrm{UCB}$ \\
\hline Number of individuals & 248 & 161 & 192 & 19 & 54 \\
\hline Individuals mean $( \pm \mathrm{Sd})$ & $6.5 \pm 14.4$ & $5.8 \pm 10.8$ & $8 \pm 17.1$ & $0.5 \pm 1.83$ & $1.4 \pm 2.03$ \\
\hline Number of samples & 38 & 28 & 24 & 39 & 77 \\
\hline Min. and max. rainfall (mm) & $44-475$ & $44-336$ & $32-353$ & $49-503$ & $54-475$ \\
\hline rs & $0.406^{*}$ & $0.478^{*}$ & $0.520 * *$ & $0.386^{*}$ & $0.372 * *$ \\
\hline Average of min.temp. $\left({ }^{\circ} \mathrm{C}\right)$ & 16.2 & 13.7 & 15.6 & 13.6 & 19.8 \\
\hline rs & $0.734 * *$ & n.s. & $0.542 * *$ & n.s. & $0.534 * *$ \\
\hline Average of max. temp. $\left({ }^{\circ} \mathrm{C}\right)$ & 31.1 & 30.4 & 30.6 & 30.8 & 31.9 \\
\hline rs & $0.666^{* *}$ & n.s. & n.s. & n.s. & $0.459 * *$ \\
\hline
\end{tabular}

* Correlation is significant at the 0.05 level; ** Correlation is significant at the 0.01 level (2-tailed; n.s. Correlation is not significant).

Table III. Meteorological data (rainfall and temperatures) observed in monthly samples, abundance of individuals (number and mean \pm SD) and values of Spearman's rank correlation coefficient (rs) of M. amoena for all localities in Bauru region (SP), Brazil (legends are the same of Table 1).

\begin{tabular}{|c|c|c|c|c|c|}
\hline & PPAVL & PPAD & ESB & ESC & $\mathrm{UCB}$ \\
\hline Number of individual & 45 & 199 & 9 & 7 & 6 \\
\hline Individuals mean $( \pm \mathrm{Sd})$ & $1.2 \pm 2.6$ & $7.1 \pm 12.0$ & $0.38 \pm 1.24$ & $0.18 \pm 0.6$ & $0.0 \pm 0.27$ \\
\hline Number of samples & 38 & 28 & 24 & 39 & 77 \\
\hline Min. and max. rainfall $(\mathrm{mm})$ & $44-475$ & $22-353$ & $44-353$ & $45-315$ & $112-253$ \\
\hline rs & n.s & $0.408 *$ & n.s. & n.s. & n.s. \\
\hline Average of min. temp. $\left({ }^{\circ} \mathrm{C}\right)$ & 16.2 & 12.0 & 16.7 & 13.9 & 19.8 \\
\hline rs & $0.646^{* *}$ & n.s. & n.s. & n.s. & $0.283 *$ \\
\hline Average of max. temp. $\left({ }^{\circ} \mathrm{C}\right)$ & 31.1 & 30.4 & 29.9 & 30.6 & 31.1 \\
\hline rs & $0.590 * *$ & n.s. & n.s. & n.s. & $0.358 * *$ \\
\hline
\end{tabular}

* Correlation is significant at the 0.05 level; ** Correlation is significant at the 0.01 level (2-tailed; n.s. Correlation is not significant). 

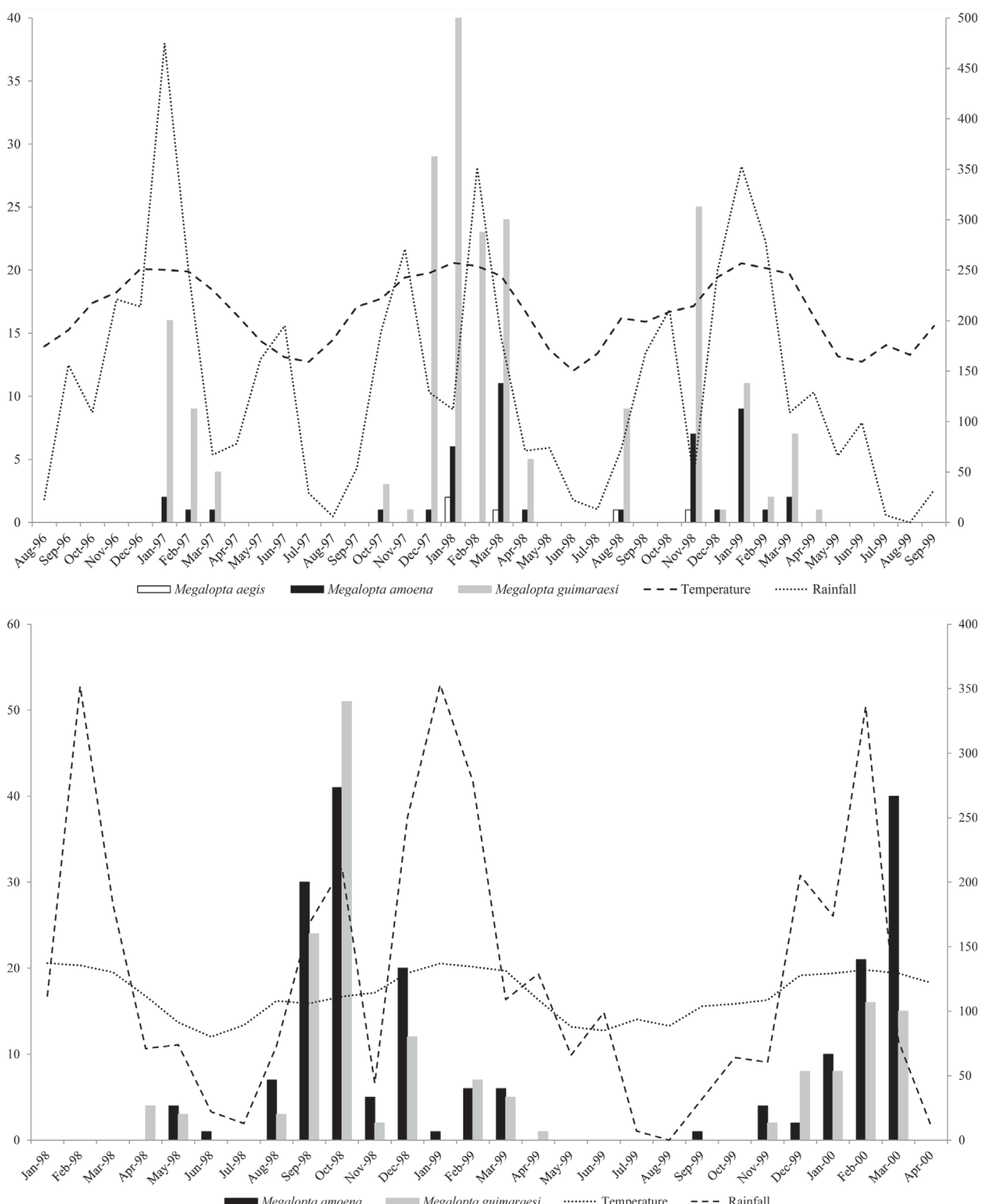

Figs. 1-2. Abundance of Megalopta, accumulated rainfall $(\mathrm{mm})$ and average of minimum temperature $\left({ }^{\circ} \mathrm{C}\right)$ at the: 1, Permanent Preservation Area Vargem Limpa-Campo Novo (PPAVL), Bauru (SP), Brazil; 2, Permanent Preservation Area of Duratex (PPAD) in Agudos (SP), Brazil.

bees, observed at UCB (during the years of 1995, 1996, and 1999) and at ESC where bees were completely absent in collections amidst 1997 and 2000 (Figs. 4-5).

Coumpond Atractiveness. In general, the more attractive compounds for Megalopta were eugenol (54\%), methyl salicylate (22\%), and eucalyptol (16\%); vanillin, benzyl acetate, and skatole attracted few individuals all together (8\%) (Table IV).

At PPAD, the preference for eugenol was more evident for M. guimaraesi (54\%) and M. amoena (88\%). M. aegis was captured with benzyl acetate $(n=3)$, eucalyptol $(n=2)$, and eu- genol $(\mathrm{n}=1)$. No significant differences were detected between them $($ Pearson chi-square $=217.592 ;$ G.L. $=20 ; \mathrm{P}=0.001)$.

\section{DISCUSSION}

This study shows the importance of the use of bait traps to sample other bees, including Megalopta and Megaloptilla (Halictidae, Augochlorini), Ptiloglossa (Colletidae, Caupolicanini), Lestrimellita (Apidae, Apini), and Acanthopus (Apidae, Ericrocidini) (Campos et al. 1989; Melo 1995; Engel \& Brooks 1999; Gonzalez et al. 2010b; Nemésio \& Siqueira 

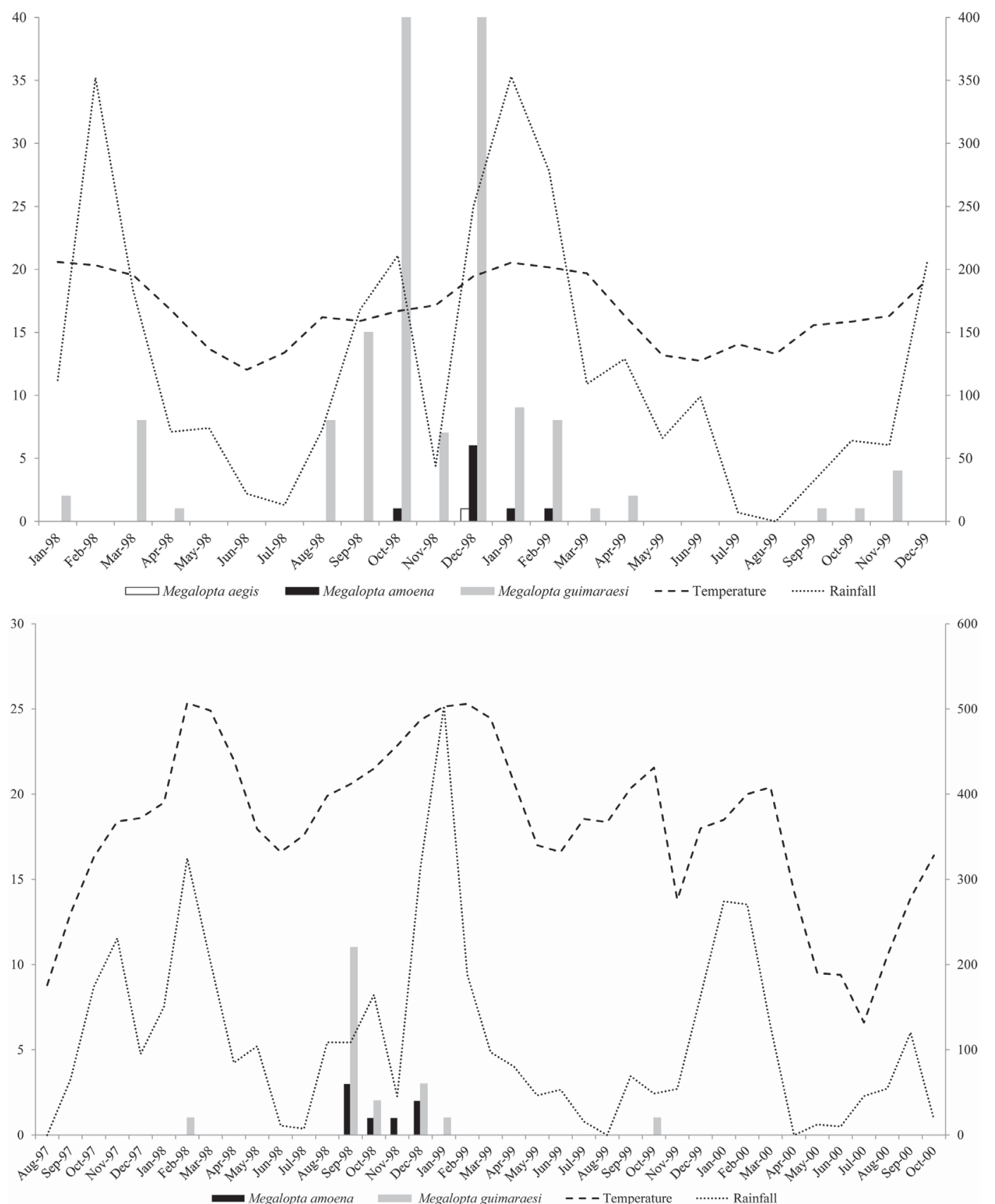

Figs. 3-4. Abundance of Megalopta, accumulated rainfall (mm) and average of minimum temperature $\left({ }^{\circ} \mathrm{C}\right)$ at the: 3 , Ecological Station of Bauru (ESB), Bauru, (SP), Brazil; 4, Ecological Station of Caetetus (ESC), Alvinlândia, Gália (SP), Brazil.

2011). Bait traps for orchid bees could be left overnight to attract dim-light bees and such data use as an additional set of information in biodiversity surveys. Sampling Megalopta with orchid bee baits could potentially be included in the established collecting protocols for rapid assessment of the bee fauna, as suggested by Santos \& Silveira (2009).

Bee Abundance and Seasonality. In Bauru region, the activity of Megalopta began in the later months of the dry season and the highest abundance peak occurred during the wet season. The same seasonal patterns related with rainfall have been reported from Panama, where these bees have been intensively studied (Wolda \& Roubik 1986; Wcislo et al. 2004).

Wcislo et al. (2004) observed that nest provisioning began at the start of the dry season, when the rains end. The oviposition was more frequent during the dry season and the first months of the wet season, and no eggs were found in nests at the end of the wet season. The estimated time of emergence to adult is 35 days (Wcislo et al. 2004). Such information helps us to explain the seasonal pattern observed in this study. Thus, our data suggest that Megalopta in Bauru region have an annual life cycle with more than one repro- 


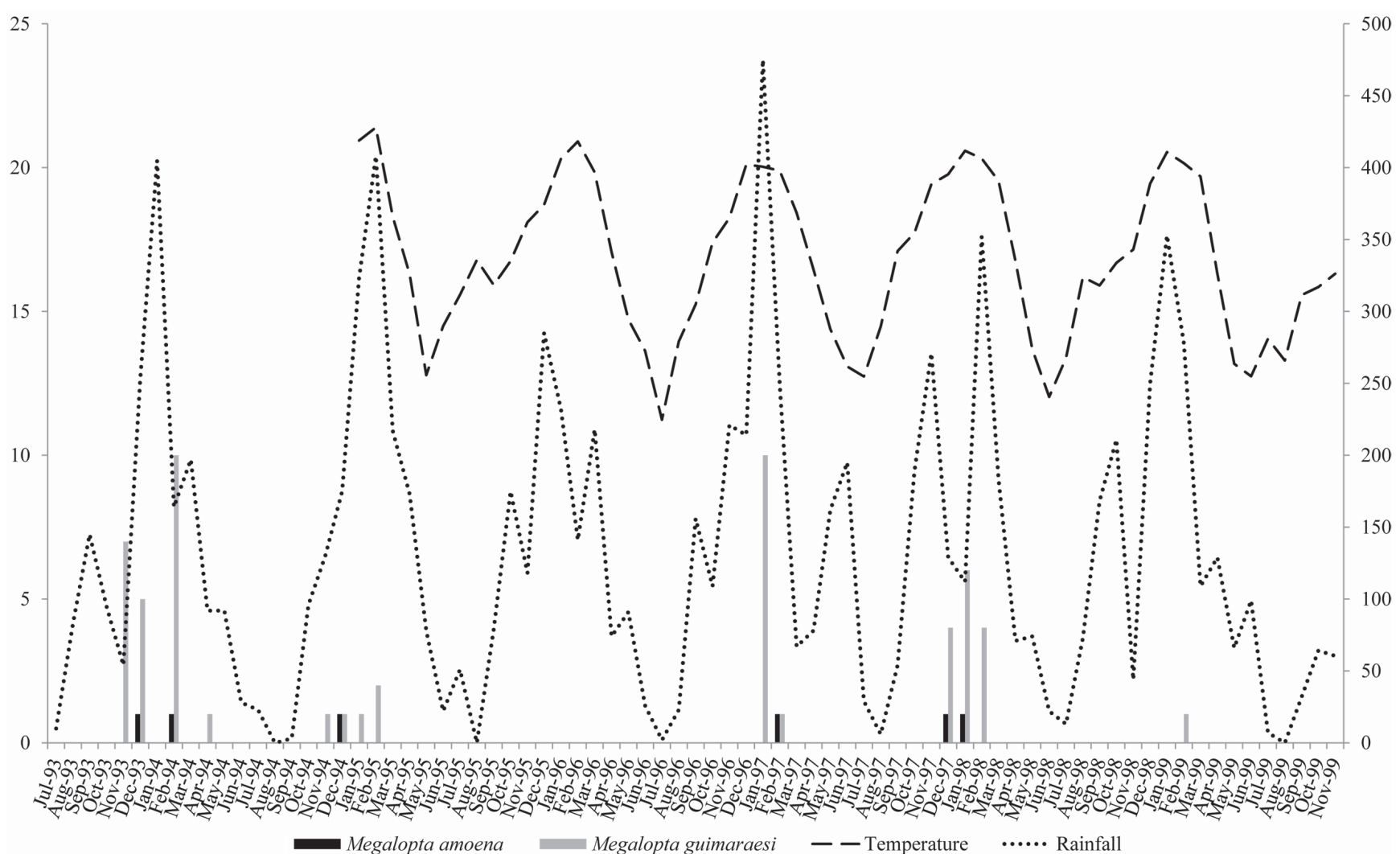

Fig. 5. Abundance of Megalopta, accumulated rainfall ( $\mathrm{mm}$ ) and average of minimum temperature $\left({ }^{\circ} \mathrm{C}\right)$ at the University $\mathrm{Campus}$ of Bauru (UCB), Bauru (SP), Brazil.

Table IV. Number of individuals of $M$. guimaraese and $M$. amoena attracted by aromatic compounds used in bait traps for all localities in Bauru region (SP), Brazil (legends are the same of Table I).

\begin{tabular}{|c|c|c|c|c|c|c|}
\hline Aromatic compounds & PPAVL & PPAD & ESB & $\mathrm{ESC}$ & UCB & Total \\
\hline \multicolumn{7}{|l|}{ Megalopta guimaraesi } \\
\hline Eugenol & $91(36 \%)$ & $87(54 \%)$ & $93(42 \%)$ & $8(42 \%)$ & $8(15 \%)$ & $287(43 \%)$ \\
\hline Methyl salicylate & $89(36 \%)$ & $43(27 \%)$ & $42(16 \%)$ & $3(16 \%)$ & $12(22 \%)$ & $189(28 \%)$ \\
\hline Eucalyptol & $64(26 \%)$ & $16(10 \%)$ & $46(37 \%)$ & $7(37 \%)$ & $6(11 \%)$ & $139(21 \%)$ \\
\hline Vanillin & $4(2 \%)$ & $15(9 \%)$ & $10(5 \%)$ & $1(6 \%)$ & $18(33 \%)$ & $48(7 \%)$ \\
\hline Benzyl acetate & - & - & 0 & - & $8(15 \%)$ & $8(1 \%)$ \\
\hline Skatole & - & - & $1(0 \%)$ & - & $2(4 \%)$ & $3(0 \%)$ \\
\hline Total & 248 & 161 & 192 & 19 & 54 & 674 \\
\hline \multicolumn{7}{|l|}{ Megalopta amoena } \\
\hline Eugenol & $37(82 \%)$ & $176(88 \%)$ & $6(67 \%)$ & $2(29 \%)$ & $2(33 \%)$ & $223(84 \%)$ \\
\hline Methyl salicylate & $5(11 \%)$ & $10(5 \%)$ & $2(22 \%)$ & $1(14 \%)$ & 0 & $18(7 \%)$ \\
\hline Eucalyptol & $2(4 \%)$ & $7(4 \%)$ & 0 & $2(29 \%)$ & 0 & $11(4 \%)$ \\
\hline Vanillin & $1(2 \%)$ & $6(3 \%)$ & $1(11 \%)$ & $2(29 \%)$ & $3(50 \%)$ & $13(5 \%)$ \\
\hline Benzyl acetate & - & - & 0 & - & $1(17 \%)$ & $1(0 \%)$ \\
\hline Skatole & - & - & 0 & - & 0 & 0 \\
\hline Total & 45 & 199 & 9 & 7 & 6 & 266 \\
\hline
\end{tabular}

ductive period during the wet season. The seasonality and the interannual variation in the abundance of Megalopta have been also observed in Panama (Roubik \& Wolda 2001).

In the Cerrado habitat, the abiotic factors, namely temperature, humidity, and rainfall, influence the induction and control of flowering plants and consequently the interaction with pollinators - bees (Gottsberger \& SilberbauerGottsberger 2006). In the Cerrado, it was observed that the blooming presented a continuous temporal standard of distribution, with the predominance of species that show annual events of blooming and fruit production; however, the peak of flowers bud and anthesis happened in months of hy- 
dric stress, July and August (Pirani et al. 2009), on the contrary to the seasonal pattern of Megalopta, which increases in abundance from this period and with higher peaks in December - January. Though the authors have verified flowers every year, they testified evidences of supra-annual variation in the amount of produced flowers (Pirani et al. 2009). This temporal dynamic of resources must be related to the interannual variation in the Megalopta individual abundance, both in diapause periods and abundance periods. In this way, abiotics factors induced the flowering and, consequently, the abundance of Megalopta bees.

The floral odors and compound attractiveness. Females forage on flowers to collect nectar and pollen, which is necessary for larval development. In Mexico and Panama, Megalopta uses many plant species for pollen (Gonzalez et al. 2010a; Tierney et al. 2012), which have both diurnal and nocturnal anthesis (Falcão et al. 1992; Ervik \& Feil 1997; Hopkins et al. 2000; Gressler et al. 2006; Oliveira et al. 2009), during either the dry or wet season (Wcislo et al. 2004). Given the similar seasonal pattern of Megalopta observed in this study in comparison with that recorded in Central America (Wolda \& Roubik 1986), we assume that the attractiveness of bait traps might be related to the fragrance produced by the flowers that produce nectar, pollen or both.

In flowers, pollen produces fragrances for multiple functions in pollination and defense (Dobson \& Bergström 1999). Furthermore, insects can perceive pollen odor and use it to discriminate between different pollen types and host plants, so pollen odor influences bee foraging, including the location of pollen sources (Dobson \& Bergström 1999). The fact that only females have been captured in the orchid bee baits suggests that they use olfactory clues to search for pollen during dim-light conditions. Some species of plants used by dim light bees that also produce scents are Prestoea schultzeana (Arecaceae), Parkia velutina (Fabaceae), and Ternstroemia dentata (Theaceae) (Ervik \& Feil 1997; Melo 1995; Hopkins et al. 2000). If this is correct, the olfactory system may have also played as important a role in the evolution of Megalopta as the visual system (Greiner et al. 2004, 2005; Kelber et al. 2005; Warrant 2004).

The compound that attracted more Megalopta was eugenol (a benzenoid substance) (Dobson \& Bergström 1999), possibly because it lasts longer in the field when compared to eucalyptol, which is a highly volatile. The others compounds used have low volatility. The attractiveness for chemical compounds observed in this study may reflect the preference, and/or presence, for chemical compounds found in flowers generally visited by Megalopta. Futures studies can test such hypotheses.

\section{ACKNOWLEDGEMENTS}

We are thankful to the "Instituto Agronômico de Campinas" and "Instituto de Pesquisas Meteorológicas da UNESP" (IPEMET) for meteorological data. To VH Gonzalez and anonymous reviewers who made significant comments that helped to improve this note. Partial support was provided by Conselho Nacional de Desenvolvimento Científico e Tecnológico (CNPq), Ph.D. Scholarship 140949/2010-0 (to L.M.S).

\section{REFERENCES}

Arneson, L. \& W. T. Wcislo. 2003. Dominant-subordinate relationships in a facultatively social, nocturnal bee, Megalopta genalis (Hymenoptera: Halictidae). Journal of the Kansas Entomological Society 76: 183193

Campos, L. A. O.; F. A. Silveira; M. L. de Oliveira; C. V. M. Abrantes; E. F. Morato \& G. A. R. Melo. 1989. Utilização de armadilhas para a captura de machos de Euglossini (Hymenoptera: Apoidea). Revista Brasileira de Zoologia 6: 621-626.

Cavassan, O.; O. Cesar \& F. R. Martins. 1984. Fitossociologia da vegetação arbórea da Reserva Estadual de Bauru, Estado de São Paulo. Revista Brasileira de Botânica 7: 91-106.

Cavassan, O.; P. G. P. Silva \& T. Seniciato. 2006. O ensino de Ciências, a biodiversidade e o cerrado, p. 190 219. In: Araújo, E. S. N. N.; J. J. Caluzi \& A. M. de A. Caldeira (Eds.). Divulgação Científica e Ensino de Ciências: Estudos e Experiências v. 7, São Paulo, Escrituras, 256 p.

Dobson, H. E. M. \& G. Bergsrtöm. 2000. The ecology and evolution of pollen odors. Plant Systematics and Evolution 222: 63-87.

Dodson, C. H.; R. L. Dressler; H. G. Hills; R. M. Adams \& N. H. Williams. 1969. Biologically active compounds in orchid fragrances. Science 164: $1243-1249$.

Durigan, G.; G. A. D. C. Franco; M. Saito \& J. B. Baitello. 2000. Estrutura e diversidade do componente arbóreo da floresta na Estação Ecológica dos Caetetus, Gália, SP. Revista Brasileira de Botânica 23: 369-381.

Engel, M. S. \& R.W. Brooks. 1999. The Augochlorine Bee Genus Megaloptilla (Hymenoptera: Halictidae). University of Kansas Natural History Museum Special Publication 24: 9-15.

Engel, M. S. 2011. Noctoraptor in Bolivia (Hymenoptera: Halictidae). Journal of the Kansas Entomological Society 84: 64-70.

Ervik, F. \& J. P. Feil. 1997. Reproductive Biology of the Monoecious Understory Palm Prestoea schultzeana in Amazonian Ecuador. Biotropica 29: 309-317.

Falcão, M. de A.; S. A. do N. Fereira; C. R. Clement; T.C. dos Santos \& R. de M. Souza.1992. Crescimento e fenologia de Araçá-Pera (Psidium acutangulum DC). Acta Amazonica 22: 285-293.

Gonzalez, V. H.; T. Griswold \& R. Ayala. 2010a. Two new species of nocturnal bees of the genus Megalopta (Hymenoptera: Halictidae). Revista de Biologia Tropical 58: 255-263.

Gonzalez, V. H.; C. Rasmussen \& A. Velasquez. 2010b. Una especie nueva de Lestrimelitta y un cambio de nombre en Lasioglossum (Hymenoptera: Apidae, Halictidae). Revista Colombiana de Entomología 36: 319-324.

Gottsberger, G \& I. Silberbauer-Gottsberger. 2006. Life in the Cerrado: a South American Tropical Seasonal Ecosystem. Vol. I. Origin, Strucutre, Dynamics and Plant Use. Ulm, Reta Verlag, 277 p.

Greiner, B.; W. A. Ribi \& E. J. Warrant. 2004. Retinal and optical adaptations for nocturnal vision in the halictid bee Megalopta genalis. Cell and Tissue Research 316: 377-90.

Greiner, B.; W. A. Ribi \& E. J. Warrant 2005. A neural network to improve dim-light vision? Dendritic fields of first-order interneurons in the nocturnal bee Megalopta genalis. Cell and Tissue Research 322: 313 320 .

Gressler, E.; M. A. Pizo \& L. P. C. Morellato. 2006. Polinização e dispersão de sementes em Myrtaceae do Brasil. Revista Brasileira de Botânica 29: $509-530$

Hopkins, M. J. G; H. C. F. Hopkins \& C. A. Sothers. 2000. Nocturnal pollination of Parkia velutina by Megalopta bees in Amazonia and its possible significance in the evolution of chiropterophily. Journal of Tropical Ecology 16: 733-746.

Janzen, D. H. 1968. Notes on nesting and foraging behavior of Megalopta (Hymenoptera: Halictidae) in Costa Rica. Journal of the Kansas Entomological Society 41: 342-350. 
Kelber, A.; E. J. Warrant; M. Pfaff; R.Wallén; J. C. Theobald; W. T. Wcislo \& R. Raguso. 2006. Light intensity limits foraging activity in nocturnal and crepuscular bees. Behavioral Ecology 17: 63-72.

Melo, G. A. R. 1995. Fragrance gathering by Euglossa males in flowers of Ternstroemia dentata (Theaceae). (Hymenoptera: Apidae: Euglosssinae). Entomologia Generalis 19: 281-283.

Michener, C. D. 2007. The Bees of the World. Second edition. Baltimore, Johns Hopkins University Press, 972 p.

Nemésio, A. 2007. The community structure of male orchid bees along the Neotropical region. Revista Brasileira de Zoociências 9: 151-158.

Nemésio, A. \& E. L. Siqueira. 2011. Acanthopus excellens Schrottky, 1902 (Hymenoptera: Apidae: Ericrocidini) attracted to eugenol in southeastern Brazil. North-Western Journal of Zoology 7: 164-166.

Oliveira, F. P. M.; M. L. Absy \& I. S. Miranda. 2009. Recurso polínico coletado por abelhas sem ferrão (Apidae, Meliponinae) em um fragmento de floresta na região de Manaus - Amazonas. Acta Amazonica 39: $505-518$.

Peel, M. C.; B. L. Finlayson \& T. A. McMahon. 2007. Updated world map of the Köppen-Geiger climate classiûcation. Hydrology and Earth System Sciences 11: 1633-1644.

Pirani, F. R.; M. Sanchez \& F. Pedroni. 2009. Fenologia de uma comunidade arbórea em cerrado sentido restrito, Barra do Garças, MT, Brasil. Acta Botânica Brasilica 23: 1096-1109.

Roubik, D. W. \& H. Wolda. 2001. Do competing honey bees matter? Dynamics and abundance of native bees before and after honey bee invasion. Population Ecology 43: 53-62.

Santos, L. M. \& F. A. Silveira. 2009. Taxonomic notes on Megalopta Smith, 1853 (Hymenoptera: Halictidae: Augochlorini) with a synopsis of the species in the state of Minas Gerais, Brazil. Zootaxa 2194: 1-20.
Santos, L. M.; S. M. Tierney \& W. T. Wcislo. 2010. Nest descriptions of Megalopta aegis (Vachal) and M. guimaraesi Santos \& Silveira (Hymenoptera, Halictidae) from the Brazilian Cerrado. Revista Brasileira de Entomologia 54: 332-334.

Tierney, S. M.; O. Sanjur; G. G. Grajales; L. M. Santos; E. Bermingham \& W. T. Wcislo. 2012. Photic niche invasions: phylogenetic history of the dim-light foraging augochlorine bees (Halictidae). Proceedings of the Royal Society B 279: 794-803.

Veloso, H. P.; A. L. R. Rangel Filho \& J. C. A. Lima. 1991. Classificação da vegetação brasileira, adaptada a um sistema universal. Rio de Janeiro, Fundação do Instituto Brasileiro de Geografia e Estatística, $124 \mathrm{p}$.

Warrant, E. J.; A. Kelber; A. Gislén; B. Greiner; W. Ribi \& W. T. Wcislo. 2004. Nocturnal vision and landmark orientation in a tropical halictid bee. Current Biology 14: 1309-1318.

Wcislo, W. T.; L. Arneson; K. Roesch; V. Gonzalez; A. Smith \& H. Fernandez. 2004. The evolution of nocturnal behavior in sweat bees, Megalopta genalis and M. ecuadoria (Hymenoptera: Halictidae): an escape from competitors and enemies? Biological Journal of the Linnean Society 83: 377-387.

Wcislo W.T. \& V. H. Gonzalez. 2006. Social and ecological contexts of trophallaxis in facultatively social sweat bees, Megalopta genalis and M. ecuadoria (Hymenoptera, Halictidae). Insectes Sociaux 53: 220225.

Wcislo, W. T. \& S. M. Tierney. 2009. Behavioural environments and niche construction: the evolution of dim-light foraging in bees. Biological Reviews of the Cambridge Philosophical Society 84: 19-37.

Wolda, H. \& D. W. Roubik. 1986. Nocturnal bee abundance and seasonal bee activity in a Panamanian forest. Ecology 67: 426-433.

Received 20/12/2011; accepted 13/11/2012

Editor: Maria Cristina Gaglianone 